\title{
HAK CIPTA PADA PENYEBARAN INFORMASI DI INDONESIA
}

\author{
ATHIATUL HAQQI, S.IPI., M.IKOM \\ e_mail: athiatul.haqqi@yahoo.co.id

\begin{abstract}
FAKULTAS ADAB DAN HUMANIORA UIN SULTHAN THAHA SAIFUDDIN JAMBI
\end{abstract}

\begin{abstract}
ABSTRAK
Tulisan ini bertujuan untuk mengungkapkan tentang perlindungan informasi. Dimana, tindakan perlindungan kekayaan intelektual atau disebut Hak Cipta ini bertujuan untuk melindungi seseorang agar terhindar dari kegiatan-kegiatan pencurian informasi dari para plagiator yang ingin mengklaim karya orang lain sebagai karyanya. Undang-undang yang mengatur tentang Hak Cipta di Indonesia dimulai sejak dekade 80-an dengan diberlakukannya Undang-Undang Nomor 6 Tahun 1982 tentang Hak Cipta yang kemudian berturut-turut diamandemen dengan Undang-Undang Nomor 7 Tahun 1987 dan Undang-Undang Nomor 12 Tahun 1997 sampai dengan diberlakukannya Undang-Undang Hak Cipta yang terbaru yaitu Undang-Undang Nomor 19 Tahun 2002 dan berlaku secara efektif dimulai pada tanggal 23 Juli 2003.
\end{abstract}

Kata Kunci: Hak Cipta, Undang-Undang Hak cipta

\section{A. PENDAHULUAN}

Setiap ide-ide ataupun gagasan yang cemerlang dan kreatif yang tercipta dari seseorang ataupun kelompok sebagai bentuk dari kemampuan intelektual manusia yang berguna, bermanfaat dan memberi dampak baik dari berbagai aspek perlu di akui dan perlu dilindungi, agar ide-ide maupun gagasan cemerlang dan kreatif yang telah diciptakan tidak diklaim atau di bajak oleh pihak lain. Untuk itu diperlukan wadah yang dapat membantu dan menaungi ide-ide cemerlang dan kreatif tersebut.Untuk tingkat internasional organisasi yang mewadahi bidang HaKI (Hak atas Kekayaan Intelektual) adalah WIPO (World Intellectual Property Organization).

Di Indonesia sendiri untuk mendorong dan melindungi penciptaan, penyebarluasan hasil kebudayaan di bidang karya ilmu pengetahuan, seni, dan sastra serta mempercepat pertumbuhan kecerdasan kehidupan bangsa, maka dirasakan perlunya perlindungan hukum terhadap hak cipta.Perlindungan hukum tersebut dimaksudkan sebagai upaya untuk mewujudkan iklim yang lebih baik untuk tumbuh dan berkembangnya gairah mencipta di bidang ilmu pengetahuan, seni dan sastra di tengah-tengah masyarakat Indonesia.

Undang-undang yang melindungi karya cipta adalah Undang-undang Nomor 6 Tahun 1982 tentang hak cipta, dan telah melalui beberapa perubahan dan telah diundangkan. Undang-Undang yang terbaru yaitu Undang-Undang No. 19 Tahun 2002 tentang Hak Cipta 
yang mulai berlaku 12 (dua belas) bulan sejak diundangkan. Tidak hanya karya cipta, invensi di bidang teknologi (hak paten) dan kreasi tentang penggabungan antara unsur bentuk, warna, garis (desain produk industri) serta tanda yang digunakan untuk kegiatan perdagangan dan jasa (merek) juga perlu diakui dan dilindungi dibawah perlindungan hukum. Dengan kata lain Hak atas Kekayaan Intelektual (HaKI) perlu didokumentasikan agar kemungkinan dihasilkannya teknologi atau karya lainnya yang sama dapat dihindari atau dicegah.

\section{B. PEMBAHASAN}

\section{Definisi Hak Cipta}

Hak Kekayaan Intelektual (selanjutnya disingkat HKI) menurut Utomo (2010: 1) adalah terjemahan resmi dan Intellectual Property Rights.Berdasarkan substansinya, HKI berhubungan erat dengan benda tidak berwujud serta melindungi karya intelektual yang lahir dari cipta, rasa dan karsa manusia.Meskipun subtansinya jelas, mencari sebuah definisi yang terdapat untuk HKI yang bersifat komprehensif dan mencangkup semua aspek, bukanlah sebuah pekerjaan yang mudah.Definisi yang bersifat lebih umum dikemukakan oleh Jill McKeough dan Andrew Stewart (1997) HKI adalah "sekumpulan hak yang diberikan oleh hukum untuk melindungi investasi ekonomi dari usaha-usaha yang kreatif”. Menurut Ditjen HKI bekerjasama dengan ECAP mendefinisikan HKI sebagai "hak yang timbul bagi hasil olah pikir otak yang menghasilkan suatu produk atau proses yang berguna untuk manusia. (Utomo, 2010: 2)

Menurut Usman (2003: 86) secara yuridis, istilah Hak Cipta telah dipergunakan dalam UUHC (1982) sebagai pengganti istilah hak perorangan yang digunakan dalam Auteurswet 1912. Dalam Pasal 1 angka 1 UUCH 2002 telah dirumuskan pengertian Hak Cipta, yang jika diperbandingkan ternyata tidak jauh berbeda dengan yang dirumuskan dalam pasal Pasal 2 Auteurswet maupun maupun Pasal 2 UUCH 1997. Pasal 1 angka 1 UUHC 2002 berbunyi:

"Hak cipta adalah hak eksklusif bagi pencipta maupun penerima hak untuk mengumumkan atau memperbanyak Ciptaannya atau memberikan izin untuk itu dengan tidak mengurangi pembatasan-pembatasan menurut peraturan perundang-undangan yang berlaku”.

Terdapat dua unsur penting yang terkandung dalam rumusan pengertian Hak Cipta yang termuat dalam Pasal 1 angka 1 UUCH 2002 tersebut, yaitu: pertama, hak yang dapat dipindahkan, dialihkan kepada pihak lain dan kedua, hak moral yang dalam keadaan bagaimanapun dan dengan jalan apapun tidak dapat ditiggalkan daripadanya, mencantumkan 
nama sebenarnya atau nama samarannya dan mempertahankan keutuhan atau integritas ceritanya.

\section{Dasar Hukum Hak Cipta di Indonesia}

Di bidang peraturan perundang-undangan, sampai dengan akhir Maret 2003 Indonesia telah menyelesaikan seluruh perundang-undangan pokok di bidang HKI, yaitu:

a. Undang-undang Nomor 19 Tahun 2002 tentang Hak Cipta (yang menggantikan Undangundang Nomor 12 tahun 1997 tentang Perubahan Undang-undang Nomor 6 tahun 1981 tentang Hak Cipta sebagaimana telah diubah dengan Undang-undang Nomor 6 Tahun 1987).

b. Undang-undang Nomor 14 Tahun 2001 tentang Paten (yang menggantikan Undangundang Nomor 13 Tahun 1997 tentang Perubahan Undang-Undang Nomor 6 tahun 1989 tentang Paten).

c. Undang-Undang Nomor 15 Tahun 2001 tentang Merek (yang menggantikan UndangUndang Nomor 14 Tahun 1997 tentang Perubahan Undang-Undang Nomor 19 Tahun 1992 tentang Merek).

d. Undang-Undang Nomor 30 Tahun 2000 tentang Rahasia Dagang.

e. Undang-Undang Nomor 31 Tahun 2000 tentang Desain Industri.

f. Undang-Undang Nomor 32 Tahun 2000 tentang Desain Tata Letak Sirkuit Terpadu; dan

g. Undang-Undang Nomor 29 Tahun 2000 tentang Perlindungan Varietas Tanaman

\section{Perlindungan Informasi Melalui Hak Cipta}

Definisi informasi, menurut UU nomor 14/2008 tentang keterbukaan informasi publik yang disebut informasi adalah keterangan, pernyataan gagasan, dan tanda-tanda yang mengandung nilai, makna, dan pesan, baik data, fakta, maupun penjelasannya, yang dapt dilihat,, didenngar dan dibaca yang disajikan dalam berbagai kemasan dan format sesuai dengan perkembagan teknologi informasi dan komunikasi secara elektronik ataupun nonelektronik (pasal 1 ayat 1). (Rumi, 2014: 23)

Pengertian secara leksikal kata perlindungan dalam hal ini menunjukkan pada peristiwa atau perbuatan.Perlindungan juga diartikan sebagai hal atau perbuatan yang berupa pemberian jaminan atas keamanan, ketentraman, kesejahteraan dan kedamaian dari pelindung kepada yang dilindungi dari bahaya atau resiko yang mengancamnya.Perlindungan Hukum berasal dari bahasa Belanda rechtsbescherming van de burgers tegen de overhead.Sedangkan Henry C. Black menyatakan legal protection of the individualinrelation to acts of administrative authorities.Perlindungan tidak hanya berdasarkan hukum tertulis tetapi juga termasuk hukum tidak tertulis dengan harapan ada jaminan terhadap benda yang dimiliki 
dalam menjalankan hak dan kewajibannya.Prinsip perlindungan hukum bagi rakyat Indonesia adalah prinsip pengakuan dan perlindungan terhadap harkat dan martabat manusia yang bersumber pada prinsip negara hukum yang berdasar pada Pancasila. Hak cipta pada dasarnya telah dikenal sejak dahulu kala, akan tetapi konsep hukum hak cipta dikenal di Indonesia pada awal tahun 80-an. Bila dilihat dari sejarahnya, ada dua konsep besar tentang hak cipta yang pada akhirnya saling mempengaruhi yaitu: Pertama, konsep Copyrights yang berkembang di Inggris dan negara-negara yang menganut sistem Common Law. Kedua, konsep Droit d'Auteur yang berkembang di Perancis dan negara-negara yang menganut sistem Civil Law. (Kusmawan, 2014: 138)

Lebih lanjut Kusmawan menjelaskan (2014: 139) menjelaskan bahwa Konsep copyrights adalah konsep dasar hak cipta yang lebih menekankan perlindungan hak-hak penerbit dari tindakan penggandaan buku yang tidak sah. Hal ini dapat ditelusuri dari berlakunya Dekrit Star Chamber pada tahun 1556 yang isinya menentukan izin pencetakan buku dan tidak setiap orang dapat mencetak buku. Aturan hukum lain yang secara tegas melindungi hak penerbit dari tindakan penggandaan yang tidak sah adalah Act of Anne 1709 yang dianggap sebagai peletak dasar konsep modern dalam hak cipta. Sedangkan konsep droit d'auteur lebih ditekankan pada perlindungan atas hak-hak pengarang dari tindakan yang dapat merusak reputasinya.Konsep ini didasarkan pada aliran hukum alam yang menyatakan bahwa suatu karya cipta adalah perwujudan tertinggi (alter ego) dari pencipta dan pencipta mempunyai hak alamiah untuk memanfaatkan ciptaannya.Perkembangan terakhir di Indonesia, pengertian cipta dalam undang-undang adalah hak eksklusif bagi pencipta atau penerima hak cipta untuk mengumumkan atau memperbanyak ciptaannya atau memberikan izin untuk itu dengan tidak mengurangi ketentuan dalam undang-undang yang berlaku.

Salah satu jenis HKI yang secara nyata telah memberikan kontribusi bagi peningkatan kualitas sumber daya manusia adalah karya ilmiah khususnya dalam bentuk buku.Hasil karya ilmiah tersebut dapat ditulis dalam bentuk buku cetak (printed Book) atau pun dalam bentuk buku digital $(e-B o o k)$ yang berupa file $(p d f, d o c, t x t)$ dan dapat diunduh serta dibaca melalui perangkat elektronik.Bentuk buku tersebut masing-masing mempunyai keunggulan dan kelemahan.Salah satu keunggulan buku cetak yang beredar di toko buku besar adalah memiliki dan mencantumkan International Serial Book Number (yang selanjutnya disebut ISBN).Dengan memiliki ISBN, buku cetak masih terpercaya untuk menjadi acuan akademisi sebagai referensi dalam menyusun karya ilmiahnya. 
Pengaturan hak cipta di Indonesia diawali dengan diberlakukannya Undang-Undang Nomor 6 Tahun 1982 tentang Hak Cipta yang kemudian diamandemen sebanyak 3 (tiga) kali sampai pada berlakunya Undang-Undang Hak Cipta. Hal baru yang diatur dalam UndangUndang Hak Cipta adalah diaturnya hak persewaan atau rental rights yang memang belum pernah diatur dalam Undang-Undang Hak Cipta terdahulu. Selain itu Undang-Undang Hak Cipta juga menempatkan pelanggaran terhadap hak cipta sebagai tindak pidana biasa, bukan delik aduan sebagaimana dianut dalam Undang-Undang Hak Cipta terdahulu serta memberikan kesempatan bagi pencipta dan pemilik hak cipta untuk mempertahankan haknya melalui gugatan perdata atau pun tuntutan pidana yang tertuang dalam Pasal 1 angka 1 Undang-Undang Hak Cipta.

Dari ketentuan Pasal 1 angka satu tersebut di atas Kusmawan, (2014: 140) menjelaskan sebagai berikut:

Pertama, hak cipta pada hakekatnya adalah perjanjian antara pencipta dengan pihak lain untuk mengumumkan dan atau memperbanyak ciptaannya. Konsekuensi logis dari definisi ini adalah: a). Peran pemerintah hanyalah sebagai administrator, akan tetapi tidak menerbitkan atau memberikan hak seperti paten. Hal ini tercermin dalam sistem pendaftaran hak cipta yang bersifat Negatif Deklaratif artinya setiap orang yang mendaftarkan karya ciptanya dianggap sebagai pencipta, kecuali terbukti sebaliknya (Pasal 5); b). Pada dasarnya hak cipta diakui keberadaannya apabila ciptaan itu merupakan karya original (hasil dari daya kreatifitas pencipta) dan dalam bentuk yang tetap dan nyata (fix and tangible) (Pasal 12); c). Pendaftaran ciptaan bukanlah suatu keharusan, karena tanpa pendaftaran pun karya cipta secara otomatis sudah mendapatkan perlindungan hukum (Pasal 2). Adapun cara yang diakui secara internasional sebagai berikut: 1 . Untuk karya di bidang ilmu pengetahuan, seni dan sastra cukup dengan membubuhkan tanda (C) disertai nama pencipta dan tahun penerbitan. 2 . Untuk karya rekaman (audio dan audivisial) dengan membubuhkan tanda $\mathrm{P}$ atau $\mathrm{N}$ di dalam lingkaran disertai tahun penerbitan. 3. Untuk memperkuat pengakuan perlindungan hak cipta dapat ditambahkan maklumat Todos los derechos reservados atau All Rights Reversed yang maksudnya adalah hak cipta dilindungi undang-undang. Di Indonesia, pendaftaran ciptaan bukan merupakan suatu keharusan bagi pencipta atau pemegang hak cipta, dan timbulnya perlindungan suatu ciptaan dimulai sejak ciptaan itu ada atau terwujud dan bukan karena pendaftaran. Namun demikian, surat pendaftaran ciptaan dapat dijadikan sebagai alat bukti awal di pengadilan apabila timbul sengketa di kemudian hari terhadap ciptaan.

Kedua, Undang-undang telah menetapkan secara limitatif jenis ciptaan yang dilindungi dalam bidang ilmu pengetahuan, seni dan sastra yang terdapat pada Pasal 12 
Undang-Undang Hak Cipta sebagai berikut: Buku, program komputer, pamflet, perwajahan (layout) karya tulis yang diterbitkan, dan semua hasil karya tulis lain; Ceramah, kuliah, pidato, dan ciptaan lain yang sejenis dengan itu; Alat peraga yang dibuat untuk kepentingan pendidikan dan ilmu pengetahuan.

Ketiga, jangka waktu berlakunya hak cipta berdasarkan objeknya secara umum adalah selama hidup pencipta ditambah 50 tahun setelah pencipta meninggal dunia kecuali, program komputer, sinematografi, data base, dan karya pengalihwujudan berlaku selama 50 tahun sejak pertama kali diumumkan.Sedangkan hak cipta atas susunan perwajahan karya tulis yang diterbitkan berlaku selama 50 tahun sejak pertama kali diterbitkan (Pasal 29 dan 30).

Keempat, Hak pencipta dan atau pemegang hak cipta dibagi menjadi Hak Ekonomi dan Hak Moral. Hak Ekonomi adalah mengizinkan atau melarang orang lain untuk mengumumkan dan atau memperbanyak ciptaannya. Sedangkan Hak Moral adalah hak yang melekat pada pencipta, yaitu hak yang selalu dicantumkan nama pencipta dalam setiap ciptaannya dan hak atas setiap ciptaannya terhadap perubahan isi maupun judul. Hak moral ini tidak bisa dialihkan seperti hak ekonomi.

Kelima, pemanfaatan hak cipta tidak sepenuhnya bersifat monopoli seperti paten, karena ada pengecualian yang berdasarkan pada pemanfaatan untuk kepentingan masyarakat (fair dealing), yang tidak termasuk dalam pelanggaran hak cipta. Di dalam Undang-Undang Hak Cipta terdapat 2 (dua) pasal yang mengatur pengecualian ini, yaitu sebagaimana diatur dalam Pasal 14 dan 15 Undang-Undang Hak Cipta. Salah satu hal yang diatur di dalam Pasal 14 dan bukan merupakan pelanggaran Hak Cipta adalah tentang pengumuman dan atau perbanyakan lambang negara dan lagu kebangsaan menurut sifat yang asli. Sedangkan Pasal 15 mensyaratkan pencantuman sumbernya agar tidak dianggap sebagai pelanggaran hak cipta atau plagiat.

Keenam, Undang-Undang Hak Cipta juga memberikan pilihan mekanisme bagi pencipta dan atau pemegang hak cipta untuk mempertahankan haknya dengan dua cara, yaitu: 1) Melalui gugatan perdata, sebagaimana diatur dalam Pasal 56 Undang-Undang Hak Cipta yang menyatakan bahwa pencipta atau pemegang hak cipta berhak mengajukan gugatan perdata, yang meliputi gugatan ganti rugi, permohonan penyitaan terhadap barang hasil pelanggaran serta permohonan penyerahan seluruh atau sebagian penghasilan dari pelanggaran. Selain itu pemegang hak cipta juga berhak meminta penetapan sementara dari hakim agar memerintahkan pelanggar menghentikan segala kegiatan pelanggaran hak cipta agar tidak timbul kerugian yang lebih besar bagi pemegang hak cipta. Gugatan perdata ini dapat di ajukan di pengadilan Niaga yang berkedudukan di 4 kota besar di Indonesia yaitu 
Medan, Jakarta, Surabaya, dan Makassar. Sedangkan pelanggaran atas hak moral dari pencipta tetap dapat diajukan oleh pencipta atau ahli warisnya bila pencipta telah meninggal dunia; 2) Melalui tuntutan pidana, pengajuan gugatan perdata dalam pelanggaran hak cipta tidak menggugurkan hak negara untuk melakukan tuntutan pidana.Pasal 72 Undang-Undang Hak Cipta telah mengatur ketentuan pidana dengan sanksi pidana yang cukup tinggi.

\section{KESIMPULAN}

Perlindungan informasi merupakan sebuah tindakan melindungan kekayaan intelektual seseorang agar terhindar dari kegiatan-kegiatan pencurian informasi dari para plagiator yang ingin mengklaim karya orang lain sebagai karyanya. Perlindungan ini telah diakui melalui Undang-undang yang bernama Undang-undang Hak Cipta dalam konteks informasi, dimana dalam undang-undang tersebut telah dipaparkan dengan jelas pasal-demi pasal beserta konsekuensi yang akan diberikan kepada siapa yang melanggar undang-undang hak cipta tersebut sesuai pasal yang telah ditetapkan.

Undang-undang yang mengatur tentang Hak Cipta di Indonesia adalah Peraturan tentang hak cipta dalam satu sistem hukum Hak Kekayaan Intelektual. Sebenarnya, Hak Cipta telah dimulai sejak dekade 80-an dengan diberlakukannya Undang-Undang Nomor 6 Tahun 1982 tentang Hak Cipta yang kemudian berturut-turut diamandemen dengan UndangUndang Nomor 7 Tahun 1987 dan Undang-Undang Nomor 12 Tahun 1997 sampai dengan diberlakukannya Undang-Undang Hak Cipta yang terbaru yaitu Undang-Undang Nomor 19 Tahun 2002 dan kemudian baru berlaku efektif pada tanggal 23 Juli 2003. 


\section{DAFTAR PUSTAKA}

Kusmawan, Denny.Perlindungan Hak Cipta Atas Buku.PerspektifVolume XIX No 2 Mei 2014.

Rumani, Sri. 2014. Aspek Hukum dan Bismis Informasi.Tengerang Selatan:Universitas Terbuka.

Rumani, Sri. 2014. Aspek Hukum dan Bisnis Informasi.Tengerang Selatan:Universitas Terbuka.

Sulistyo-Basuki. 1991. Pengantar Ilmu Perpustakaan.Cet. 1. Jakarta: Gramedia Pustaka Utama.

Usman,Rahmadi. 2003. Hukum Hak Atas Kekayaan Intelektual. Bandung: P.T. Alumni.

Utomo,Tomi Suryo. 2010. Hak Kekayaan (HKI) di Era Global: Sebuah Kajian Kontemporer. Yogyakarta: Graha Ilmu. 